\title{
Aedes aegypti and Aedes albopictus (Diptera: Culicidae): coexistence and susceptibility to temephos, in municipalities with occurrence of dengue and differentiated characteristics of urbanization
}

\author{
Aedes aegypti e Aedes albopictus (Diptera: Culicidae): coexistência e suscetibilidade ao \\ temephos, em municípios com ocorrência de casos de dengue e diferentes características de \\ urbanização
}

\section{Josiane Somariva Prophiro ${ }^{1,2}$, Onilda Santos Silva ${ }^{3}$, Jonny Edward Duque Luna ${ }^{2}$, Carla Fernanda Piccoli ${ }^{2}$, Luiz Alberto Kanis ${ }^{4}$ and Mario Antonio Navarro da Silva ${ }^{2}$}

\begin{abstract}
Introduction: The aim of the present study was to verify the coexistence between Aedes aegypti and Aedes albopictus populations in municipalities of the States of Paraná and Santa Catarina with different urbanization profiles where dengue occurs and evaluate their susceptibility to the organophosphate temephos. Methods: The number of eggs per ovitrap were counted and incubated for hatching to identify the species. Data analysis of the populations was conducted to determine randomness and aggregation, using the variance-to-mean ratio (index of dispersion). Susceptibility to temephos was evaluated by estimation of the resistance ratios $R_{50}$ and $R_{9}$. Aedes aegypti samples were compared with the population Rockefeller and Aedes albopictus samples were compared with a population from the State of Santa Catarina and with the Rockefeller population. Results: Coexistence between Aedes aegypti and Aedes albopictus and the aggregation of their eggs were observed at all the sites analyzed in the State of Paraná. Conclusions: All the Aedes aegypti populations from the State of Parana showed alteration in susceptibility status to the organophosphate temephos, revealing incipient resistance. Similarly, all the Aedes albopictus populations (States of Paraná and Santa Catarina) presented survival when exposed to the organophosphate temephos.
\end{abstract}

Keywords: Dengue. Aedes aegypti. Aedes albopictus. Coexistence. Organophosphate.

\section{RESUMO}

Introdução: $O$ presente estudo teve como objetivo verificar a coexistência de populações de Aedes aegypti e de Aedes albopictus em municípios do Estado do Paraná e Santa Catarina com diferentes formas de urbanização, onde ocorrem casos de dengue, e avaliar a susceptibilidade ao organofosforado temephos. Métodos: O número de ovos por ovitrampa foram contados (sem distinguir a espécie) e colocados para eclosão e posterior identificação das espécies. A análise das populacões foi conduzida para determinar aleatoriedade e agregação usando a razão variância/média (índice de dispersão). A susceptibilidade ao temephos foi avaliada para determinar e estimar as razões de resistência $\mathrm{RR}_{50} \mathrm{eRR}_{95}$. As amostras de Aedes aegypti, obtidas do Estado do Paraná, foram comparadas com a população Rockefeller e as amostras de Aedes albopictus foram comparadas com a população do Estado de Santa Catarina. Resultados: Coexistência entre Aedes aegyptie Aedes albopictus, e a agregação de seus ovos foram observados em todos os locais analisados. Conclusões: Todas as populações de Aedes aegypti do Estado do Paraná demonstraram alteração no status de susceptibilidade ao organofosforado temephos, evidenciando resistência incipiente. Assim como, todas as populacões de Aedes albopictus avaliadas, do Estado do Paraná e Santa Catarina, apresentaram sobrevivência quando expostas ao organofosforado temefós.

Palavras-chaves: Dengue. Aedes aegypti. Aedes albopictus. Coexistência. Organofosforado.

1. Grupo de Pesquisa em Imunoparasitologia, Universidade do Sul de Santa Catarina, Tubarão, SC. 2. Laboratório de Entomologia Médica e Veterinária, Universidade Federal do Paraná, Curitiba, PR. 3. Setor de Parasitologia, Departamento de Microbiologia, Universidade Federal do Rio Grande do Sul, Porto Alegre, RS. 4. Grupo de Pesquisa em Tecnologia Farmacêutica, Universidade do Sul de Santa Catarina, Tubarão, SC.

Address to: Dra. Josiane Somariva Prophiro. Av. José Acácio Moreira 787, 88704-900 Tubarão, SC, Brasil. Phone: 5548 3621-3294; Fax: 5548 3621-3108.

e-mail: josiane.prophiro@unisul.br

Received in 01/06/2010

Accepted in 10/01/2011

\section{INTRODUCTION}

Aedes aegypti is the primary vector of viral serotypes that cause dengue and urban yellow fever in the Americas, where the incidence of these arboviruses have increased significantly in the last 25 years $^{1}$. Aedes albopictus is considered a secondary vector of dengue virus in the Old World ${ }^{2}$ and in Brazil, its presence was first reported in $1986^{3}$. Currently, it is widely distributed in the country, particularly in the southern and southeastern regions. However, little is known regarding the susceptibility of Ae. albopictus to insecticides and the influence of coexistence with Ae. aegypti. Currently, Ae. albopictus is not implicated as a transmitter of the dengue virus in Brazil, so there is no control program for this Culicidae. Generally, the occurrence of dengue fever epidemics is directly related to the presence and density of vectors, when viral circulation occurs. These mosquito species can often coexist in artificial containers in urban and periurban localities ${ }^{4}$. However, immature Ae. albopictus may also inhabit natural containers, such as bromeliads, bamboo and holes in the tree trunks $s^{5}$. This plasticity of Ae. albopictus to colonize artificial containers and natural breeding sites and to coexist with other species in urban and periurban localities can increase its dispersion to new areas where control is impaired. In addition, since Ae. albopictus can colonize bromeliads, it may also expand its distribution to more protected areas. Most importantly, arbovirus circulation may cause the emergence of diseases within this ecological system ${ }^{6}$.

Due to the ability of both species to coexistent and colonize the same breeding places, it is expected that the pressure exerted by control with insecticides affects these species in very similar manner. Changes in the susceptibility of Ae. albopictus to chemical insecticides, similar to that which has been occurring with Ae. aegypti, could be observed in the near 
future $^{7,8}$. This is a problem that can be detected in advance and resulted in the inclusion of this species in the National Network for the Resistance Monitoring of Ae. aegypti to Insecticides (Rede Nacional de Monitoramento da Resistência de Ae. aegypti, MoReNAa $)^{9-11}$.

The emergence of resistant populations has caused serious problems for mosquito control. Changes in susceptibility have been identified for all classes of insecticides, directly affecting the re-emergence of diseases transmitted by vectors ${ }^{12}$. Regardless of important advances in alternative methodologies, chemical insecticides are a powerful tool against vectors and will continue to play an important role in integrated control ${ }^{13}$, at least until the discovery of alternative methods that permit fast, safe, and sustainable control of vectors.

In the process of entomological surveillance, it is very important to monitor the biological behavior of these vectors and the resistance development process ${ }^{14}$.

The objective of this study was to verify the coexistence of $A e$. aegypti and Ae. albopictus populations and their aggregation and susceptibility to the insecticide temephos, in municipalities with differentiated urbanization characteristics where dengue occurs.

\section{METHODS}

\section{Area of study and collection of material}

In partnership with the Secretary of State for Health of Paraná, oviposition traps (ovitraps) were set with a $500 \mathrm{~mL}$ of $10 \%$ hay solution. The ovitraps (345) were randomly distributed in peridomiciliary areas at various points of the following municipalities: Ubiratã, Santa Helena, Foz do Iguaçu South Sector, and Foz do Iguaçu North Sector. In the City of Ubiratã, two collections were conducted due to low hatching. These municipalities had autochthonous cases of dengue in the summer of 2006-2007. Besides Ae. albopictus populations in the State of Paraná, a population of Ae. albopictus in the town of Tubarão, State of Santa Catarina, was also evaluated, which had no history of temephos application. Monitoring the susceptibility of Aedes spp. the State of Santa Catarina is very important because this state is the only state in Brazil that has no record of autochthonous case of dengue (Figure 1).

The ovitraps were randomly placed per area for 5 days in peridomiciles inside the urban area (in residential neighborhoods and downtown) of the municipalities with confirmed records of dengue and/or Aedes spp. and according to the recommendations of the National Health Foundation ${ }^{10}$.

\section{Study of Aedes populations}

In the laboratory, the eggs of each ovitrap were counted (no species distinction) and placed individually for hatching, rearing and subsequent recording of males and females of both species (species distinction). Adults were then placed in cages to obtain the $\mathrm{F}_{1}$ larvae generation, which was used in the temephos susceptibility bioassays. The whole process, including egg storage and adult breeding, was performed under controlled temperature $\left(25 \pm 2^{\circ} \mathrm{C}\right)$ and relative humidity $(80 \pm 10 \%)$ under 1 h photophase.

Data analysis of the populations to determine randomness and aggregation and the distribution of eggs per ovitrap was calculated using variance-to-mean ratio (index of dispersion), here called equation 1 .

$\mathrm{I}=\frac{\mathrm{S}^{2}}{\hat{\mathrm{m}}}$ equation 1 : where $\mathrm{I}=$ index of dispersion, $\mathrm{S}^{2}=$ variance $\mathrm{m}^{\wedge}=$ mean

Values lower than 1 suggest regular or uniform spatial arrangement, values equal to 1 indicate random spatial arrangement, while values significantly higher than 1 show aggregate arrangement ${ }^{15,16}$.

The aggregation index was indicated by the $\mathrm{k}$ parameter of the negative binomial distribution. Negative $k$ values indicate uniform distribution, low and positive values $(\mathrm{k}<2)$ indicate a highly aggregated arrangement, $\mathrm{k}$ values ranging from 2 to 8 indicate moderate aggregation and $\mathrm{k}$ values above $8(\mathrm{k}>8)$ indicate a random arrangement $^{16-18}$.

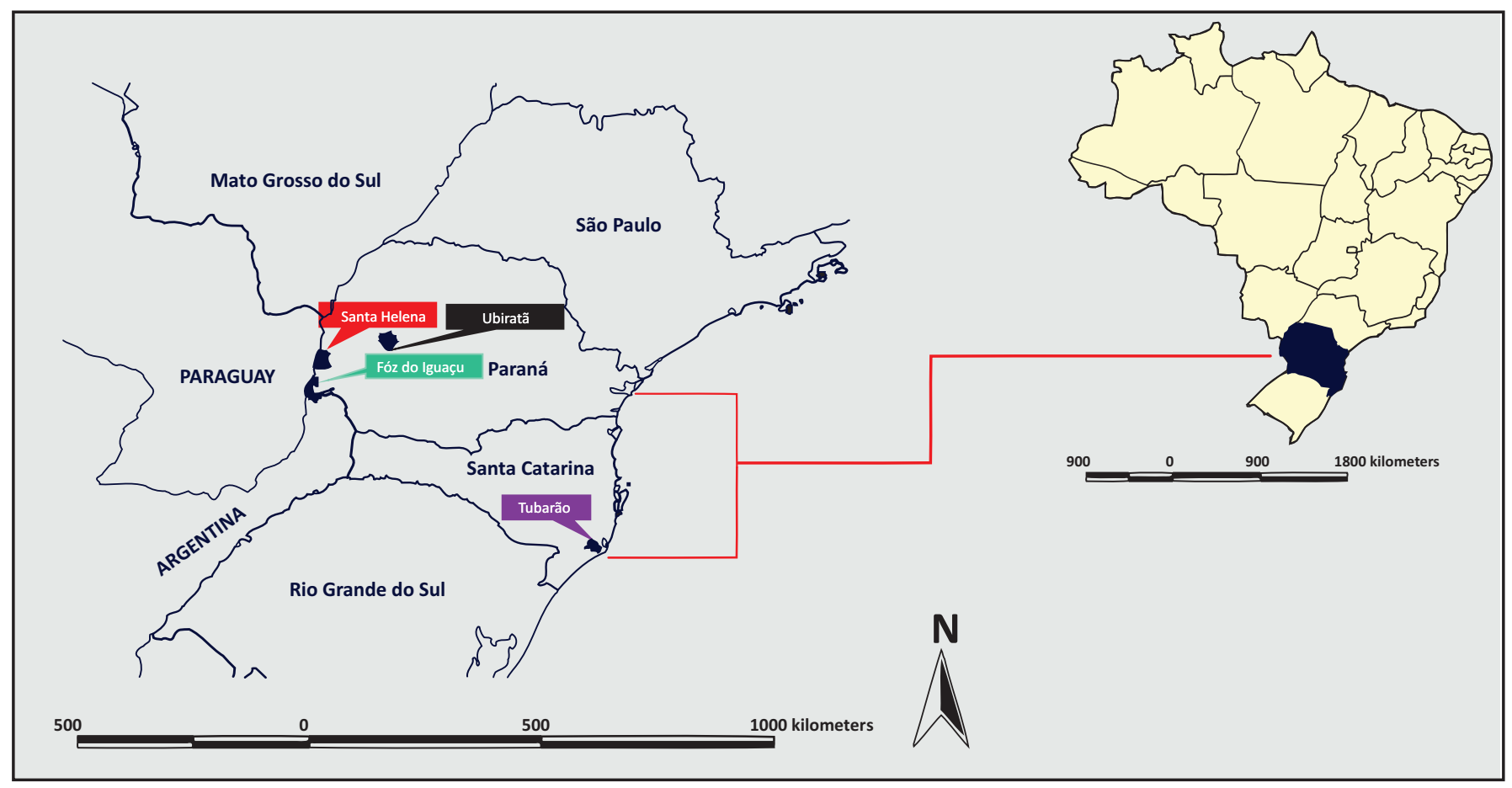

FIGURE 1 - Map of Brazil, showing the cities analyzed in the State of Parana and Santa Catarina, Brazil. 
The results were analyzed with the program Statistica version 7.0. Only data with $\mathrm{p}<0.05$ were considered significant. The nonparametric tests Kruskal-Wallis (KW) and Mann-Whitney U (MW) were applied in order to verify statistical differences between the species and municipalities evaluated.

\section{Temephos bioassays}

The larvicide used was $90 \%$ technical grade temephos, batch 002/2005, manufactured by the Fersol Mairinque Laboratory, City of São Paulo. The bioassays consisted of a dose-response of temephos with 640 late third or early fourth instars of each Ae. aegypti and Ae. albopictus populations. Four replicates of 20 larvae, totaling 80 larvae per concentration were exposed to eight different concentrations of temephos, including the diagnostic dose. This diagnostic concentration was applied to qualitatively detect the presence of individuals resistant to the susceptible strain, 0.0060 $\mathrm{mg} / \mathrm{L}$ (as previously determined by our laboratory) for this same batch of insecticide, corresponding to twice the $\mathrm{CL}_{99}$ of the Rockefeller susceptible strain, as recommended elsewhere. Additionally, four replicates of 20 larvae, totaling 80 larvae of each population were exposed to ethanol solvent, as negative control ${ }^{19-21}$.

The Rockefeller reference strain was used as control for Ae. aegypti and Ae. albopictus. Due to lack of a reference population of Ae. albopictus for analysis of susceptibility to insecticides, a population of the Rockefeller reference strain was used.

Larval mortality was observed after $24 \mathrm{~h}$ of exposure to temephos. Larvae were considered to have died when they were unable to reach the water surface when touched. The tests were repeated four times on different days and all tests were performed under controlled temperature $\left(25^{\circ} \mathrm{C} \pm 1\right)$ and photoperiod $(12: 12)$ in a climatic chamber model CDG-347 Fanem ${ }^{\otimes 19,20,22}$.

\section{Criteria for evaluation of susceptibility and statistical analysis}

The criteria used to detect qualitative changes in susceptibility status of the populations analyzed followed the protocol of Davidson \& Zahar ${ }^{23}$ : a) mortality above $98 \%$ in response to the diagnostic concentration is considered susceptible; b) between 98 and $80 \%$ suggests incipient resistance status; and c) less than $80 \%$ mortality indicates resistance.

The rate of resistance $\left(R_{50}\right.$ and $\left.R_{95}\right)$ as a quantitative indicator was calculated by dividing the lethal concentrations $\left(\mathrm{LC}_{50}\right.$ and $\left.\mathrm{LC}_{95}\right)$ of each population studied by the lethal concentrations ( $\mathrm{LC}_{50}$, $\mathrm{LC}_{95}$ ) of the Rockefeller colony, for Ae. aegypti and Ae. albopictus. Resistance levels were classified as low $\mathrm{RR}<5.0$, medium $(5.0<\mathrm{RR}<10.0)$ or high $(\mathrm{RR}>10.0)^{24}$. To determine the lethal concentrations $\left(\mathrm{LC}_{50}, \mathrm{LC}_{95}\right), X^{2}$ test, slope and confidence intervals from the GW-Basic Probit program were used ${ }^{25}$.

\section{RESULTS}

\section{Study of Aedes populations}

Of the 345 ovitraps installed, 63\% were positive for eggs $(11,220)$, which resulted in 6.132 adults $(3,222 / 53 \%$ Ae. aegypti and $2.910 / 47 \%$ Ae. albopictus). The positive traps and the percentage of adult males and females in both species, in different regions of collection, are presented in Table 1.

The number of eggs and the number of emerged adults from each of the localities showed significant differences. The relationship between sex ratio was close to the expected, 1:1 in all municipalities for both species (Table 1).

The variance-to-mean ratio (index of dispersion) for eggs of Ae. aegypti and Ae. albopictus exhibited values significantly higher than 1 , indicating highly aggregated distribution in all the municipalities studied (independent of the species). Similarly, the values obtained with the k parameter of the negative binomial also indicated aggregate distribution of egg samples in all the municipalities studied, whose values were always positive between zero and eight (Table 2).

\section{Temephos bioassays}

Following exposure of the populations evaluated to the diagnostic concentration $0.0060 \mathrm{mg} / \mathrm{L}$, analysis verified that the population of Foz do Iguaçu, in both the south and north sectors, presented status resistant. For the municipalities of Ubiratã and Santa Helena, the Ae. aegypti populations were susceptible to temephos. All the Ae. albopictus populations evaluated, from Paraná and the population of Tubarão, Santa Catarina, showed survival when exposed to the diagnostic concentration of the organophosphate temephos (Table 3).

For the populations of Ae. aegypti from municipalities of the State of Paraná submitted to bioassays using different concentrations (CM) of temephos, the $\mathrm{RR}_{95}$ was: 1.70 for Ubiratã, PR; 1.65 for Santa Helena, PR; 3.62 for Foz do Iguaçu south, PR; and 3.13 for Foz do Iguaçu north, PR (Table 4). For the populations of Ae. Albopictus from municipalities of Santa Catarina and Paraná submitted to bioassays using different concentrations (CM) of temephos, the $R_{95}$ was: 2.01 for Tubarão, SC; 1.97 for Ubiratã, PR; 2.36 for Santa Helena, PR; 2.23 for Foz do Iguaçu south, PR; and 2.58 for Foz do Iguaçu north, PR (Table 4).

In general, the slope values of the Ae. aegypti and Ae. albopictus populations studied were lower compared to those obtained of the Rockefeller strain. This finding confirmed their heterogeneity compared to the reference strain and the differences in their response to the insecticide. The lethal concentrations and resistance rates of populations in all the municipalities are presented for comparison in Table 4.

TABLE 1 - Aedes aegypti and Aedes albopictus collected with ovitraps in the municipalities of Ubiratã, Santa Helena, Foz do Iguaçu north and Foz do Iguaçu south during the summer of 2006-2007.

\begin{tabular}{|c|c|c|c|c|c|c|c|c|c|c|}
\hline Localities & $\begin{array}{c}\text { Ovitraps }^{*} \\
\text { installed/positive }\end{array}$ & $\begin{array}{c}\text { Eggs } \\
\mathrm{n}\end{array}$ & $\begin{array}{c}\text { Adults } \\
\mathrm{n}\end{array}$ & $\begin{array}{c}\text { Emergence } \\
\% \\
\end{array}$ & $\begin{array}{l}\text { Aedes } \\
\text { aegypti }\end{array}$ & $q$ & $\begin{array}{l}\text { Sex } \\
\text { ratio }\end{array}$ & $\begin{array}{c}\text { Aedes } \\
\text { albopictus }\end{array}$ & q & $\begin{array}{l}\text { Sex } \\
\text { ratio } \\
\end{array}$ \\
\hline Ubiratã 1 & $49 / 30$ & 1,003 & 646 & 64.0 & 80 & 36 & 0.45 & 566 & 295 & 0.52 \\
\hline Santa Helena & $50 / 39$ & 2,597 & 972 & 37.0 & 482 & 252 & 0.52 & 490 & 254 & 0.52 \\
\hline Foz do Iguaçu south & $74 / 44$ & 2,058 & 1,582 & 77.0 & 1,476 & 742 & 0.50 & 106 & 54 & 0.51 \\
\hline
\end{tabular}


TABLE 2 - Dispersion indices and $K$ parameter, spatial oviposition arrangement of Aedes spp. in the municipalities of Ubiratã, Santa Helena, Foz do Iguaçu south and Foz do Iguaçu north during the summer of 2006-2007.

\begin{tabular}{lcc}
\hline Localities & Dispersion indices & K Parameter \\
\hline Ubiratã 1 & 77.43 & 0.43 \\
\hline Ubiratã 2 & 35.33 & 1.49 \\
\hline Santa Helena & 69.92 & 0.98 \\
\hline Foz do Iguaçu south & 46.85 & 1.03 \\
\hline Foz do Iguaçu north & 95.72 & 0.59 \\
\hline
\end{tabular}

TABLE 3 - Bioassays with the diagnostic concentration $0.0060 \mathrm{mg} / \mathrm{L}$ (calibrated with the Rockefeller strain) in larvae of Aedes aegypti of municipalities of Paraná and Aedes albopictus of Paraná and Santa Catarina States, in the summer of 2006-2007.

\begin{tabular}{lcc}
\hline \multirow{2}{*}{ Municipalities } & \multicolumn{2}{c}{ Mortality $(\%)$} \\
\cline { 2 - 3 } & species & $0.0060 \mathrm{mg} / \mathrm{L}$ \\
\hline Rockefeller & Aedes aegypti & 100.0 \\
\hline Tubarão (SC) & Aedes albopictus & $95.25 \pm 1.69$ \\
\hline Ubiratã (PR) & Aedes albopictus & $94.38 \pm 0.58$ \\
\hline Santa Helena (PR) & Aedes aegypti & $99.06 \pm 0.50$ \\
& Aedes albopictus & $90.94 \pm 0.96$ \\
\hline Foz do Iguaçu south & Aedes aegypti & $77.50 \pm 8.37$ \\
& Aedes albopictus & $91.56 \pm 1.26$ \\
\hline Foz do Iguaçu north & Aedes aegypti & $75.94 \pm 9.78$ \\
& Aedes albopictus & $87.19 \pm 0.96$ \\
\hline SC: State of Santa Catarina, PR: State of Paraná.
\end{tabular}

TABLE 4 - Municipalities studied, species and generation used, lethal concentrations (microgram/liter) and respective confidence interval, slope and Chi square ratio of resistance $\left(\mathrm{RR}_{50}\right.$ and $\left.\mathrm{RR}_{95}\right)$ in populations of Aedes aegypti and Aedes albopictus of municipalities in State of Paraná and Aedes albopictus of State of Santa Catarina, in the summer of 2006-2007.

\begin{tabular}{lccccccc}
\hline Municipalities & Species & $\mathrm{CL}_{50}(\mathrm{IC})$ & $\mathrm{CL}_{95}(\mathrm{IC})$ & $\mathrm{Slope}^{2}$ & $\mathrm{RR}_{50}$ & $\mathrm{RR}_{95}$ \\
\hline Rockefeller & Aedes aegypti $(\mathrm{F} n)$ & $1.67(1.64 \pm 1.70)$ & $2.93(2.82 \pm 3.06)$ & $7.68 \pm 0.14$ & 2.19 & 1 \\
\hline Tubarão(SC) & Aedes albopictus $(\mathrm{F} n)$ & $3.33(3.27 \pm 3.39)$ & $5.90(5.74 \pm 6.08)$ & $6.63 \pm 0.16$ & 5.92 & 1.99 & 2.01 \\
\hline Ubiratã (PR) & Aedes aegypti (F1) & $2.83(2.44 \pm 3.28)$ & $4.98(3.92 \pm 6.38)$ & $6.71 \pm 0.62$ & 8.47 & 1.69 & 1.70 \\
& Aedes albopictus (F1) & $3.35(3.27 \pm 3.44)$ & $5.78(5.53 \pm 6.06)$ & $6.96 \pm 0.25$ & 5.49 & 2.0 & 1.97 \\
\hline Santa Helena (PR) & Aedes aegypti (F1) & $2.59(2.40 \pm 2.75)$ & $4.83(4.60 \pm 5.14)$ & $6.10 \pm 0.49$ & 0.88 & 1.55 & 1.65 \\
& Aedes albopictus (F1) & $3.57(3.45 \pm 3.68)$ & $6.92(6.62 \pm 7.27)$ & $5.72 \pm 0.20$ & 4.95 & 2.14 & 2.36 \\
\hline Foz do Iguaçu south (PR) & Aedes aegypti (F1) & $3.83(3.61 \pm 4.03)$ & $10.62(9.96 \pm 11.44)$ & $3.71 \pm 0.17$ & 3.6 & 2.29 & 3.62 \\
& Aedes albopictus (F1) & $3.60(3.50 \pm 3.69)$ & $6.53(6.25 \pm 6.86)$ & $6.35 \pm 0.21$ & 5.11 & 2.15 & 2.23 \\
\hline Foz do Iguaçu north (PR) & Aedes aegypti (F1) & $3.73(3.53 \pm 3.91)$ & $9.16(8.66 \pm 9.76)$ & $4.21 \pm 0.19$ & 8.58 & 2.23 & 3.13 \\
& Aedes albopictus (F1) & $3.61(3.48 \pm 3.72)$ & $7.55(7.21 \pm 7.97)$ & $5.12 \pm 0.20$ & 1.76 & 2.16 & 2.58 \\
\hline
\end{tabular}

SC: State of Santa Catarina, PR: State of Paraná.

\section{DISCUSSION}

\section{Study of Aedes populations}

In the municipality of Ubiratã, collections 1 and 2, differences occurred between the predominance of species collected for Ae. albopictus (Ubiratã 1: 88\% and Ubiratã 2: 84\%) and Ae. aegypti (Ubiratã 1: 12\% and Ubiratã 2: 16\%, respectively). Ae. albopictus predominated where there was higher density of inhabitants in urban centers than in rural areas. The municipality of Ubiratã is a wooded site, which may have favored the presence and/or increased survival of Ae. albopictus in relation to Ae. aegypti.
In this study, coexistence of Ae. aegypti and Ae. albopictus was observed in all the municipalities studied in the State of Paraná, similar to that observed by Gomes et $\mathrm{al}^{26}$ and Fantinatti et $\mathrm{al}^{27}$. Fantinatti et $\mathrm{al}^{27}$ evaluated the abundance and aggregation of Ae. aegypti and Ae. albopictus eggs in several municipalities of Paraná and described the coexistence of these species in all the sites studied.

It is important to emphasize that the ovitraps in Ubiratã were installed in 2007, in the same period of the dengue outbreak, which registered cases of autochthonous dengue cases. Currently, there is no official record of the dengue virus transmission by Ae. albopictus in Brazil. Nevertheless, only by viral serotype isolation and the confirmation of virus transmission competence of Ae. albopictus 
populations from Ubiratã, will it be possible to confirm whether this species is capable of transmitting the virus dengue in the area studied.

Different from other locations, in the collections from Foz do Iguaçu, in both the South and North sectors, a higher prevalence of Ae. aegypti than Ae. albopictus was verified. This situation could be related to the higher density of inhabitants in urban centers than in rural areas. In the municipality of Santa Helena, the presence of Ae. aegypti and Ae. albopictus was equivalent. The same occurred with the mean population in rural and urban areas. These data corroborate studies by Braks et $\mathrm{al}^{28}$, who described that the habitat affects the abundance of Ae. aegypti and Ae. albopictus in both southeastern Brazil and Florida. They observed a predominance of Ae. aegypti in highly urbanized areas and Ae. albopictus in rural areas and similar abundance of both species in suburban areas.

\section{Bioassays with larvicidal}

Mortality among larvae using the Rockefeller diagnostic concentration on Ae. aegypti populations in Foz do Iguaçu north and south was less than $80 \%$, indicating that the process of selective resistance has been established. Only the Ae. aegypti populations of Ubiratã and Santa Helena were considered susceptible to temephos.

Although Ae. albopictus is not targeted in the control programs, all species populations from the State of Paraná and Santa Catarina were analyzed and showed survival against the organophosphate temephos when exposed to the diagnostic concentration. These results suggest that in locations where coexistence of Ae. aegypti and Ae. albopictus occurs both species are being exposed to the same process of selective pressure due to the insecticides applied. Thus, the high co-occurrence of Ae. aegypti and Ae. albopictus in Brazil, in areas under intense selective pressure of insecticides, may justify the survival of Ae. albopictus populations tested for temephos. These results also suggest that Ae. albopictus populations could become resistant to temephos in the near future, as is currently occurring with Ae. aegypti in several Brazilian states. In addition, the laboratory sample of Ae. albopictus from Santa Catarina probably originates from an environment with previous use of organophosphates in agriculture and thus, certain mechanisms of persistence or even resistance to this compound may have been previously selected.

Changes in the susceptibility status of Ae. aegypti to temephos have been previously reported in Brazil and in Malaysia ${ }^{29}$, Thailand ${ }^{30-32}$, India ${ }^{33}$, Cambodia ${ }^{34}$ and Venezuela ${ }^{24}$. For Ae. albopictus, monitorization of the development of resistance to temephos has been reported in Malaysia $^{35-37}$ and Thailand ${ }^{32,38}$, India ${ }^{33}$ and Italy ${ }^{39}$.

Following the criteria of Mazzari \& Georghiou ${ }^{24}$, all Ae. aegypti (PR) and Ae. albopictus populations (PR and SC) presented $\mathrm{RR}_{50}$ and $\mathrm{RR}_{95}$ values at low levels. The same was determined by Duque et al ${ }^{40}$ and Duque et $\mathrm{al}^{41}$ for Ae. aegypti populations in other municipalities of the State of Paraná, including Curitiba, Foz do Iguaçu, Paranavaí, Maringá, Ibiporã, Cambé and Jacarezinho.

The $\mathrm{RR}_{50}$ and $\mathrm{RR}_{95}$ values determined by Duque et $\mathrm{al}^{41}$ for $A$ e. aegypti populations of Foz do Iguaçu, collected in 2005, were 2.6 and 3.9 , respectively. In the present study, the values of $R R_{50}$ and $R R_{95}$, determined for the populations of Foz do Iguaçu, collected in 2007, were 2.29 and 3.62 for Foz do Iguaçu south and 2:23 and 3:13 to Foz do Iguaçu north, respectively. In comparisons between the values of $\mathrm{RR}_{50}$ and $\mathrm{RR}_{95}$ of Duque et al. ${ }^{41}$ with the $\mathrm{RR}_{50}$ and $\mathrm{RR}_{95}$ of this study, a decrease was verified; however, to explain the decrease in $R R_{50}$ and $\mathrm{RR}_{95}$ values, long-term monitoring of these populations is required.
The $\mathrm{RR}_{50}$ and $\mathrm{RR}_{95}$ values observed in Paraná and Santa Catarina for the populations studied are considered low, similar to those for some municipalities in São Paulo ${ }^{42,43}$. However, in several Brazilian states (Rio de Janeiro ${ }^{7}$, Alagoas ${ }^{7}$, Sergipe $^{7}$ and Ceará ${ }^{8}$ ), medium and high resistance status was observed ${ }^{21}$. According to Câmara et $\mathrm{al}^{44}$ and Duque et $\mathrm{al}^{41}$, the southern region of Brazil shows lower values for $\mathrm{RR}_{50}$ and $\mathrm{RR}_{95}$ compared with other regions. This is probably due to reduced vector densities in the cold seasons, together with lower selective pressure due to less intense use of insecticides.

Although the Ae. aegypti and Ae. albopictus populations tested showed low levels of susceptibility to temephos, constant resistance monitoring of these populations to insecticides is of great importance. Such studies can provide early warning of the problem and alert us to the need for new strategies to control the vectors of dengue in southern Brazil in the coming years.

\section{ACKNOWLEDGMENTS}

The authors are grateful to the Secretary of State for Health of Paraná, particularly to Allan Martins, the coordinator of the Entomology Division, for his cooperation in sending the material for the bioassays. The authors would also like to thank André Souza Leandro from the Secretary of State for Science and Technology of Paraná and the Zoonosis Control Center in Foz do Iguaçu.

\section{CONFLICT OF INTEREST}

The authors declare that there is no conflict of interest.

\section{FINANCIAL SUPPORT}

Conselho Nacional de Desenvolvimento Científico e Tecnológico (CNPq).

\section{REFERENCES}

1. Gubler DJ. The emergence of epidemic dengue fever and dengue hemorrhagic fever in the Americas: a case of failed public health policy. Rev Panam Salud Publica 2005; 17: 221-224.

2. Shroyer D. Aedes albopictus and arboviruses: a concise review of the literature. J Am Mosq Control Assoc 1986; 2: 424-428.

3. Forattini OP. Identificação de Aedes (Stegomya) albopictus (Skuse) no Brasil. Rev Saude Publica 1986; 20:5

4. Honório NA, Cabello PH, Codeço CT, Lourenço-de-Oliveira R. Preliminary data on the performance of Aedes aegypti and Aedes albopictus immatures developing in water-filled tires in Rio de Janeiro. Mem Inst Oswaldo Cruz 2006; 101:225-228.

5. Hawley WA. The biology of Aedes albopictus. J Am Mosq Control Assoc 1988; 4 (suppl 1):1-40.

6. Natal D, Urbinatti PR, Taipe-Lagos CB, Cereti Júnior W, Diederichsen AT, Souza RG, et al. Aedes (Stegomyia) albopictus (Skuse) breeding in Bromeliaceae in the outskirts of an urban area of the city of Sao Paulo, Brazil. Rev Saude Publica 1997; 31:517-518.

7. Braga IA, Lima JBP, Silva SS, Valle D. Aedes aegypti resistance to temephos during 2001 in several municipalities in states of Rio de Janeiro, Sergipe, and Alagoas, Brazil. Mem Inst Oswaldo Cruz 2004; 99:199-203.

8. Lima EP, Oliveira AMF, Lima JWO, Ramos ANJ, Cavalcanti LPG, Pontes RJS. Resistência do Aedes aegypti ao temefós em municípios do Estado do Ceará. Rev Soc Bras Med Trop 2006; 39:259-263.

9. World Health Organization. Vector Resistance to Pesticides. $15^{\text {th }}$ report. Geneva: World Health Organization Expert Committee on Vector Biology and Control; 1992. 
10. Fundação Nacional de Saúde. Programa Nacional de Controle da Dengue. Brasília: Ministério da Saúde; 2002.

11. Braga IA, Valle D. Aedes aegypti: vigilância, monitoramento da resistência e alternativas de controle no Brasil. Epidemiol Serviços Saude 2007; 16:113-118.

12. Brogdon WG, McAllister JC. Insecticide resistance and vector control. Emerg Infect Dis 1998; 4:605-613.

13. Thatheyus JA. Biocontrol of mosquitoes In: William SJ, editor. Defeating the public enemy, the mosquito: a real challenge. Chennai: Loyola College; 2007. p. 76-94.

14. Chen CD, Nazni WA, Lee HL, Sofian-Azirun M. Weekly variation on susceptibility status of Aedes mosquitoes against temephos in Selangor, Malaysia. Trop Biomed 2005; 22:195-206.

15. Rabinovich JE. Introducción a la ecología de poblaciones animales. México: Continental; 1980.

16. Pereira MFA, Boiça Jr. AL, Barbosa JC. Distribuição espacial de Bemisia tabaci (Genn.) Biótipo B (Hemiptera: Aleyrodidae) em feijoeiro (Phaseolus vulgaris L.). Neotrop Entomol 2004; 33:493-498.

17. Pielou EC. Mathematical ecology. $2^{\text {nd }}$ ed. New York: Wiley; 1977.

18. Southwood TRE. Ecological methods. London: Chapman and Hall; 1978.

19. World Health Organization. Instructions for determining the susceptibility or resistance of mosquito larvae to insecticides. Geneva; 1981.

20. World Health Organization. Criteria and Meaning of Tests for Determining the Susceptibility or Resistance of Insects to Insecticides. Geneva; 1981.

21. Lima JBP, Pereira da Cunha M, Silva-Jr RCS, Galardo AKR, Soares SS, Braga IA, et al. Resistance of Aedes aegypti to organophosphates in several municipalities in the state of Rio de Janeiro and Espírito Santo, Brazil. Am J Trop Med Hyg 2003; 68:329-333.

22. Robertson JL, Preisler HK. Pesticide bioassays with arthropods. Boca Raton: CRC Press; 1992.

23. Davidson G, Zahar DA. The practical implications of resistance of malaria vectors to insecticides. Bull World Health Organ 1973; 49:475-483.

24. Mazzari MB, Georghio GP. Characterization of resistance to organophosphate, carbamate, and pyrethroid insecticides in field populations of Aedes aegypti from Venezuela. J Am Mosq Control Assoc 1995; 11:315-322.

25. Finney DJ. Probit Analysis. $3^{\text {rd }}$ ed. Cambridge (UK): Cambridge University Press; 1971.

26. Braks MA, Honório NA, Lourenco-De-Oliveira R, Juliano SA, Lounibos LP. Convergent habitat segregation of Aedes aegypti and Aedes albopictus (Diptera: Culicidae) in southeastern Brazil and Florida. J Med Entomol 2003; 40:785-794.

27. Gomes AC, Souza JMP, Bergamaschi DP, Santos JLF, Andrade VR, Leite OF, et al. Anthropophilic activity of Aedes aegypti and of Aedes albopictus in area under control and surveillance. Rev Saude Publica 2005; 39:206-210.

28. Fantinatti ECS, Duque JEL, Silva AM, Navarro-Silva MA. Abundance and aggregation egg of Aedes aegypti L. and Aedes albopictus (Skuse) (Diptera: Culicidae) in the north and northwest of the State of Parana, Brazil. Neotrop Entomol 2007; 36:960-965.

29. Lee HL, Lime W. A re-evaluation of the susceptibility of field collected Aedes (Stegomyia) aegypti (Linnaeus) larvae to temephos in Malaysia. Mosq Borne Dis Bull 1989; 6:91-95.

30. Chareonviriyaphap T, Aum-aung B, Ratanatham S. Current insecticide resistance pattern in mosquito vectors in Thailand. Southeast Asian J Trop Med Public Health 1999; 30:184-194.

31. Paeporn P, Komalamisra N, Deesin V, Rongsriyam Y, Eshita Y, Thongrungkiat S. Temephos resistance in two forms of Aedes aegypti and its significance for the resistance mechanism. Southeast Asian J Trop Med Public Health 2003; 34:786-792.

32. Jirakanjanakit N, Saengtharatip S, Rongnoparut P, Duchon S, Bellec C, Yoksan $\mathrm{S}$. Trend of temephos resistance in Aedes (Stegomyia) mosquitoes in Thailand during 2003-2005. Environ Entomol 2007; 36:506-511.

33. Sharma SN, Saxena VK, Lal S. Study on susceptibility status in aquatic and adult stages of Aedes aegypti and Ae. albopictus against insecticides at international airports of south India. J communicable Dis 2004; 36:177-181.
34. Polson KA, Curtis C, Chang MS, Olson JG, Chantha N, Rawlins SC. Susceptibility of two Cambodian population of Aedes aegypti mosquito larvae to temephos during 2001. Dengue Bull 2001; 25:79-83.

35. Lee HL, Asikin N, Nazni WA, Sallehuddin S. Temporal variations of insecticide susceptibility status of field-collected Aedes albopictus (Skuse) in Malaysia. Trop Biomed 1998; 15:43-50.

36. Nazni WA, Kamaludin MY, Lee HL, Rogayah TAR, Sa'diyah I. Oxidase activity in relation to insecticides resitance in vectors of public health importance. Trop Biomed 2000; 17:69-79.

37. Cheng SS, Huang CG, Chen YJ, Yu JJ, Chen WJ, Chang ST. Chemical compositions and larvicidal activities of leaf essential oils from two eucalyptus species. Bioresour Technol 2009; 100:452-456.

38. Ponlawat A, Scott JG, Harrington LC. Insecticide Susceptibility of Aedes aegypti and Aedes albopictus across Thailand. J Med Entomol 2005; 42:821-825.

39. Romi R, Toma L, Severini F, Di Luca M. Susceptibility of Italian populations of Aedes albopictus to temephos and to other insecticides. J Am Mosq Control Assoc 2003; 19:419-423.

40. Duque JEL, Martins FM, Dos Anjos FA, Kuwabara EF, Navarro-Silva MA Susceptibilidade de Aedes aegypti aos inseticidas Temephos e Cipermetrina, Brasil. Rev Saude Publica 2004; 38:842-843.

41. Duque JEL. Descrição e análise de fatores epidemiológicos, vetoriais e do controle da dengue no estado do Paraná, Brasil. Tese de doutorado. Curitiba: Paraná. Universidade Federal do Paraná; 2008. 150p.

42. Campos J, Andrade CFS. Susceptibilidade larval de duas populações de Aedes aegypti a inseticida químicos. Rev Saude Publica 2001; 35:232-236.

43. Macoris MLG, Andrighetti MT, Takaku L, Glasser CM, Garbeloto VC, Bracco JE Resistance of Aedes aegypti in the state of São Paulo, Brazil, to Organophosphates insecticides. Mem Inst Oswaldo Cruz 2003; 98:703-708.

44. Câmara PF, Theophilo GRL, Santos TG, Pereira GSRF, Câmara PDC, Matos RR Regional and dynamics characteristics of dengue in Brazil: a retrospective study. Rev Soc Bras Med Trop 2007; 40:192-196. 